\title{
PREDIKSI OUTFLOW UANG KARTAL DI KALIMANTAN BARAT DENGAN METODE SINGULAR SPECTRUM ANALYSIS (SSA)
}

\author{
Ageng Wicaksono, Helmi, Yundari
}

\begin{abstract}
INTISARI
Uang merupakan komponen penting dalam perekonomian yang digunakan sebagai alat pembayaran dalam melakukan transaksi jual dan beli. Banyaknya uang yang beredar di masyarakat berpengaruh pada kondisi perekonomian suatu negara. Dalam kewenangan untuk mengatur transaksi arus keluar/masuk uang kartal, diperlukan Rencana Kebutuhan Uang (RKU). Banyak aspek yang menjadi dasar pembuatan RKU, salah satunya data historis aliran uang masuk (inflow) dan aliran uang keluar (outflow). Agar perencanaan tersebut tepat maka peramalan outflow sangat diperlukan. Data outflow pada umumnya memuat pola musiman dan trend sehingga dapat dimodelkan dengan analisis deret waktu. Metode SSA merupakan metode yang menggunakan pendekatan nonparametrik. Artinya dalam pengaplikasiannya, metode ini tidak membutuhkan uji asumsi-asumsi parametrik. Metode SSA menguraikan data deret waktu ke dalam komponen-komponen, yaitu trend, musiman, siklis dan noise. Pada penelitian ini metode SSA yang digunakan adalah metode recurrent (R-forecasting). Penelitian ini dilakukan dengan mengelompokkan data sebanyak 3 kelompok yang menggambarkan fluktuasi data untuk 9 periode peramalan. Tingkat akurasi peramalan diukur menggunakan kriteria Mean Absolute Percentage Error (MAPE) dan Tracking Signal. MAPE dan Tracking Signal pada peramalan SSA terhadap data aktual sebesar 18,63\% dan 0,6377. Hal ini mengakibatkan metode SSA dapat dikatakan baik dan valid untuk meramalkan outflow uang kartal di Kalimantan Barat periode November 2018 sampai Juli 2019.
\end{abstract}

Kata Kunci: singular spectrum analysis, $R$-forecasting, MAPE, tracking signal

\section{PENDAHULUAN}

Uang merupakan komponen penting dalam perekonomian yang digunakan sebagai alat pembayaran dalam melakukan transaksi jual beli, baik dalam pertukaran barang ataupun jasa. Banyaknya uang yang beredar di masyarakat akan berpengaruh pada kondisi perekonomian suatu negara [1].

Bank Indonesia (BI) merupakan satu-satunya lembaga yang berwenang mengeluarkan, mengedarkan, mencabut, menarik dan memusnahkan uang Rupiah [2]. Sebagai bank sentral, BI memiliki wewenang untuk mengeluarkan dan mengedarkan uang kartal yang terdiri dari uang kertas dan uang logam [3]. Keberadaan uang kartal ini sangatlah penting bagi masyarakat, karena uang kartal inilah yang secara fungsi dipakai sebagai alat pembayaran yang sah menggantikan sistem barter, sebagai alat penyimpan nilai dan satuan penghitung [4]. Dalam kewenangan BI untuk mengatur transaksi arus keluar atau masuk uang kartal, BI membuat Rencana Kebutuhan Uang (RKU). Banyak aspek yang menjadi dasar pembuatan RKU, salah satunya data historis aliran uang masuk (inflow) dan aliran uang keluar (outflow).

Peramalan inflow dan outflow ini menjadi penting karena berhubungan dengan likuiditas perbankan yang berdampak pada kebijakan-kebijakan moneter yang harus dijalankan. Jika nilai aspek tersebut tinggi maka likuiditas bank akan naik, sedangkan jika terlalu rendah maka likuiditas bank akan turun dan terjadi inflasi. Selain itu peramalan inflow dan outflow menjadi penting karena berhubungan dengan ekonomi suatu daerah. Jika pada suatu daerah terjadi kekurangan uang maka dikhawatirkan perekonomian daerah tersebut akan kolaps atau jatuh. Sebaliknya jika jumlah uang di suatu daerah berlebih maka dikhawatirkan nilai uang tersebut akan berkurang dan terjadi inflasi [4]. 
Salah satu hal penting yang harus diramalkan dalam uraian tersebut adalah outflow. Pada umumnya data outflow memuat pola musiman dan trend sehingga dapat dimodelkan dengan analisis deret waktu. Metode SSA merupakan metode yang menggunakan pendekatan nonparametrik. Artinya dalam pengaplikasiannya, metode ini tidak membutuhkan uji asumsi-asumsi parametrik. SSA mendekomposisi data deret waktu asli menjadi suatu penjumlahan dari sejumlah kecil komponen independen seperti komponen trend, musiman, dan noise [5]. Hal ini mengakibatkan pada penelitian ini digunakan metode SSA.

SSA merupakan sebuah teknik analisis deret waktu dan peramalan. SSA mengkombinasikan elemen klasik analisis deret waktu, statistika multivariat, geometri multivariat, sistem dinamik dan pemrosesan sinyal. SSA memiliki tujuan untuk mendekomposisi sebuah rangkaian data menjadi jumlahan komponen-komponen kecil yang dapat diinterpretasikan [6]. Metode SSA yang digunakan dalam penelitian ini adalah metode recurrent (R-forecasting).

Penelitian ini diawali dengan identifikasi pola data, untuk melihat apakah pola datanya terdapat musiman atau tidak. Selanjutnya terdapat dua tahapan yang saling melengkapi dalam algoritma SSA yaitu tahap dekomposisi dan tahap rekonstruksi. Pada tahap dekomposisi, dua langkah utama yang harus dilakukan untuk memperoleh eigentriple, yaitu embedding dan singular value decomposition. Pada tahap rekonstruksi, dua langkah yang harus dilakukan untuk memperoleh deret yang direkonstruksi, yaitu pengelompokan dan diagonal averaging.

Selanjutnya dilakukan pembentukan model SSA berdasarkan nilai koefisien recurrent. Setelah diperoleh model SSA langkah selanjutnya adalah meramalkan dan menyimpulkan hasil analisis model SSA.

\section{DEKOMPOSISI}

Pada dekomposisi terdapat dua tahap yaitu Embedding dan Singular Value Decomposition (SVD). Parameter yang memiliki peran penting dalam dekomposisi adalah Window Length $(L)$.

Embedding adalah tahapan di mana data deret waktu awal diubah menjadi matriks trajectory, maksudnya mengubah data awal yang berupa data satu dimensi menjadi data berbentuk multidimensi. Matriks trajectory memiliki dimensi $L_{X} K$, di mana $L$ merupakan window length, sedangkan $K=N$ $L+1$. Rentang pemilihan nilai $L$ adalah $2<L<\frac{N}{2}$, dengan asumsi bahwa data deret waktu $X$ sepanjang periode $N$ tidak memuat data hilang, dengan $X=\left\{x_{i}\right\} ; i=1,2, \ldots N$ [5].

Matriks trajectory $\left(\mathbf{T}_{x}\right)$ yang terbentuk merupakan matriks Hankel. Matriks Hankel adalah matriks yang semua elemen di sepanjang diagonal $i+j$ konstan artinya setiap kemiringan diagonal dari kiri ke kanan adalah konstan. Matriks trajectory dapat ditulis sebagai berikut.

$$
\mathbf{T}_{x}=\left(\mathbf{T}_{i, j}\right)_{L x K}=\left[\begin{array}{cccc}
x_{1} & x_{2} & & x_{K} \\
x_{2} & x_{3} & \cdots & x_{K+1} \\
& \vdots & \ddots & \vdots \\
x_{L} & x_{L+1} & \cdots & x_{N}
\end{array}\right] .
$$

Tahapan selanjutnya dalam dekomposisi adalah Singular Value Decomposition (SVD) yang bertujuan untuk memperoleh pemisahan komponen dalam dekomposisi dari data deret waktu. SVD pada penerapannya memiliki kesamaan dengan analisis komponen utama (principal component analysis) yaitu bersifat untuk mereduksi komponen dari data awal serta mengurangi dimensi.

Hasil dari langkah SVD adalah singular value, eigenvector, dan principal component dari matriks lintasan. Matriks ini dalam setiap barisannya mengandung singular value yang merupakan akar dari eigenvalue, eigenvector, dan principal component. SVD dimulai dengan menentukan nilai eigenvalue $\left(\lambda_{1}, \lambda_{2}, \ldots, \lambda_{L}\right)$ dari matriks $\mathbf{S}$.

$$
\mathbf{S}=\mathbf{T}_{x} \mathbf{T}_{x}^{T}
$$


di mana $\lambda_{1} \geq \cdots \geq \lambda_{L}>0$, serta eigenvector $\left(U_{1}, U_{2}, \ldots, U_{L}\right)$ dari matriks $\mathbf{S}$ tersebut. Sedangkan principal component dinotasikan dengan

dengan $p=1,2, \ldots, d$

$$
\mathbf{V}=\frac{\mathbf{T}_{x}^{T} \mathbf{U}_{p}}{\sqrt{\lambda_{p}}}
$$

SVD dari matriks lintasan dituliskan sebagai $\mathbf{T}_{x p}=T_{x 1}+T_{x 2}+\cdots+T_{x d}$, dimana $\mathbf{T}_{x 1}=$ $\sqrt{\lambda_{1}} \mathbf{U}_{1} \mathbf{V}_{1}^{T}$. Matriks $\mathbf{T}_{x p}$ mempunyai rank 1, karena merupakan matriks elementer. Kumpulan dari $\left(\sqrt{\lambda_{p}}, \mathbf{U}_{p}, \mathbf{V}_{p}^{T}\right)$ disebut eigentriple ke $p$ dari SVD [5]. SVD dari matriks lintasan dapat ditulis dengan persamaan berikut.

$$
\begin{aligned}
\mathbf{T}_{x p} & =T_{x 1}+T_{x 2}+\cdots+T_{x d}, \\
\mathbf{T}_{x p} & =\sqrt{\lambda_{1}} \mathbf{U}_{1} \mathbf{V}_{1}^{T}+\sqrt{\lambda_{2}} \mathbf{U}_{2} \mathbf{V}_{2}^{T}+\cdots+\sqrt{\lambda_{d}} \mathbf{U}_{d} \mathbf{V}_{d}^{T}, \\
\mathbf{T}_{x p} & =\sum_{i=1}^{d} \sqrt{\lambda_{p}} \mathbf{U}_{p} \mathbf{V}_{p}^{T},
\end{aligned}
$$

dengan $p=1,2, \ldots, d$ dan $d=\max \{p\} ; \lambda_{p}>0$.

\section{GROUPING}

Grouping adalah tahapan pemisahan komponen-komponen aditif seperti trend, musiman, dan noise yang terdapat pada data deret waktu. Proses grouping dilakukan dengan cara mengelompokkan set-set indeks $\{1,2, \ldots, d\}$ menjadi $m$ subset yang dapat dilambangkan dengan $I_{x}=I_{1}+I_{2}+\cdots+I_{m}$ yang selanjutnya membentuk matriks yang didasarkan pada Singular Value Decomposition untuk matriks trajectory sebagai berikut.

$$
\mathbf{T}_{I x}=T_{I 1}+T_{I 2}+\cdots+T_{I m}
$$

Tahapan untuk memilih set $I_{x}=I_{1}+I_{2}+\cdots+I_{m}$ disebut dengan eigentriple grouping.

\section{DIAGONAL AVERAGING}

Diagonal averaging merupakan tahapan kedua pada rekonstruksi data. Tahapan diagonal averaging ini adalah tahapan merekonstruksi masing-masing matriks yang terdapat pada matriks $\mathbf{T}_{I x}$ menjadi data deret waktu yang baru dengan panjang $N$.

Misalkan matriks $\mathbf{Y}=L \times K ; Y_{i j}, 1 \leq i \leq L, 1 \leq j \leq K$. Matriks $\mathbf{Y}$ diubah menjadi deret waktu $g_{1}, \ldots, g_{N}$ melalui diagonal averaging yaitu:

dengan

$$
g_{k}=\left\{\begin{array}{c}
\frac{1}{k} \sum_{m=1}^{k} y_{m, k-m+1}^{*} ; 1 \leq k<L^{*}, \\
\frac{1}{L^{*}-1} \sum_{m=1}^{L^{*}-1} y_{m, k-m+1}^{*} ; L^{*} \leq k<K^{*}+1, \\
\frac{1}{N-k+1} \sum_{m=k-K^{*}+1}^{N-K^{*}+1} y_{m, k-m+1}^{*} ; K^{*}+1 \leq k \leq N,
\end{array}\right.
$$

$$
\begin{aligned}
& L^{*}=\min (L, K), \\
& K^{*}=\max (L, K), \\
& N=L+K-1, \\
& y_{i j}^{*}=\left\{\begin{array}{c}
y_{i j} ; L<K, \\
y_{i j} ; \text { selainnya } .
\end{array}\right.
\end{aligned}
$$

Misalkan $k=1$ akan dihasilkan $g_{1}=y_{11}, k=2$ akan dihasilkan $g_{2}=\frac{\left(y_{12}+y_{21}\right)}{2}$, dan seterusnya. 


\section{R-FORECASTING}

Peramalan $R$-forecasting berkaitan dengan penaksiran Linier Recurrent Formula (LRF). Apabila dimisalkan $U=\left(u_{1}, u_{2}, \ldots, u_{L-1}, u_{L}\right)^{T}, U^{\nabla}=\left(u_{1}, u_{2}, \ldots, u_{L-1}\right)^{T}$ dan $\pi_{q}$ adalah komponen terakhir dari eigenvectors $U$ atau dapat ditulis $\pi_{q}=u_{L}$ maka koefisien LRF dapat dihitung menggunakan Persamaan (5).

$$
\mathfrak{R}=\left(a_{L-1}, a_{L-2}, \ldots, a_{1}\right)^{T}=\frac{1}{1-v^{2}} \sum_{q=1}^{r} \pi_{q} U^{\nabla} .
$$

dimana $v^{2}=\sum_{q=1}^{r} \pi_{q}^{2}$.

Data deret waktu yang digunakan pada $R$-forecasting merupakan hasil rekonstruksi yang diperoleh dari diagonal averaging. Langkah selanjutnya yaitu menentukan $M$ buah titik baru untuk diramalkan. Sehingga deret hasil peramalan dapat ditulis dengan persamaan berikut.

Hasil peramalan diperoleh berdasarkan

$$
G_{N+M}=\left(g_{1}, g_{2}, \ldots, g_{N+M}\right)
$$

$$
g_{i}=\left\{\begin{aligned}
\bar{y}_{i} ; i & =0,1, \ldots, N \\
\sum_{j=1}^{L-1} a_{j} g_{i-j} ; i & =N+1, \ldots, N+M,
\end{aligned}\right.
$$

\section{MATRIKS W-CORRELATION}

Besarnya korelasi ditunjukkan oleh gradasi warna dari warna terang hingga gelap dari matriks $W$ correlation. Semakin tua warnanya semakin tinggi korelasinya [7]. Contoh dari matrix w-correlation dapat dilihat pada Gambar 3.1.

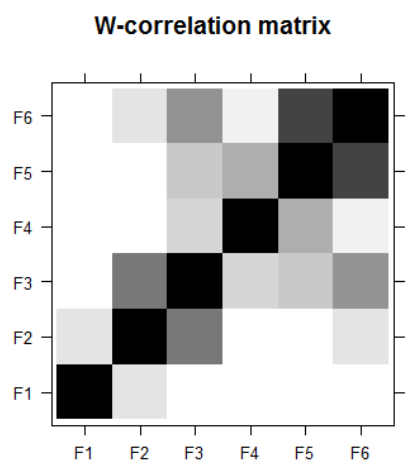

(a)

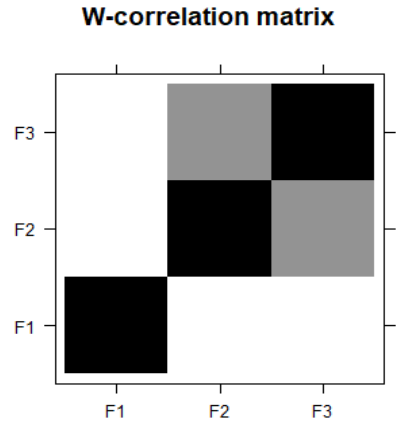

(b)

Gambar 3.1 (a) contoh matriks w-correlation lemah, (b) contoh matriks w-correlation kuat

\section{UKURAN AKURASI TRACKING SIGNAL}

Salah satu alat pengukuran akurasi peramalan lainnya untuk data deret waktu adalah nilai tracking signal. Tracking signal adalah ukuran toleransi yang dapat digunakan untuk menentukan kemungkinan apakah hasil dari peramalan dapat digunakan. Batas toleransi dari nilai tracking signal yang dapat diterima yaitu $-5 \leq$ tracking signal $\leq 5$ [8]. Dengan perhitungan sebagai berikut.

$$
\text { Tracking Signal }=\frac{\sum_{t=1}^{n} e_{t}}{\sum_{t=1}^{n} \frac{\left|e_{t}\right|}{n}},
$$

dengan $e_{t}=$ error periode ke- $t$.

\section{STUDI KASUS}

Penentuan pola data ini digunakan untuk menentukan apakah data outflow ini mengandung musiman atau tidak. Data yang digunakan pada penelitian ini merupakan data sekunder. Data yang digunakan berupa data deret waktu dengan selang waktu dari Januari 2015 sampai Oktober 2018 dalam bentuk bulanan. Data outflow tersebut dibagi menjadi data in sample dan data out sample. Data in sample yang digunakan sebesar 36 data (pada $i=1,2, \ldots, 36$ ) dan 10 data (pada $i=37,38, \ldots, 46$ ) 
digunakan sebagai data out sample. Data in sample outflow uang kartal ini dibentuk menjadi sebuah grafik yang disajikan pada Gambar 1 .

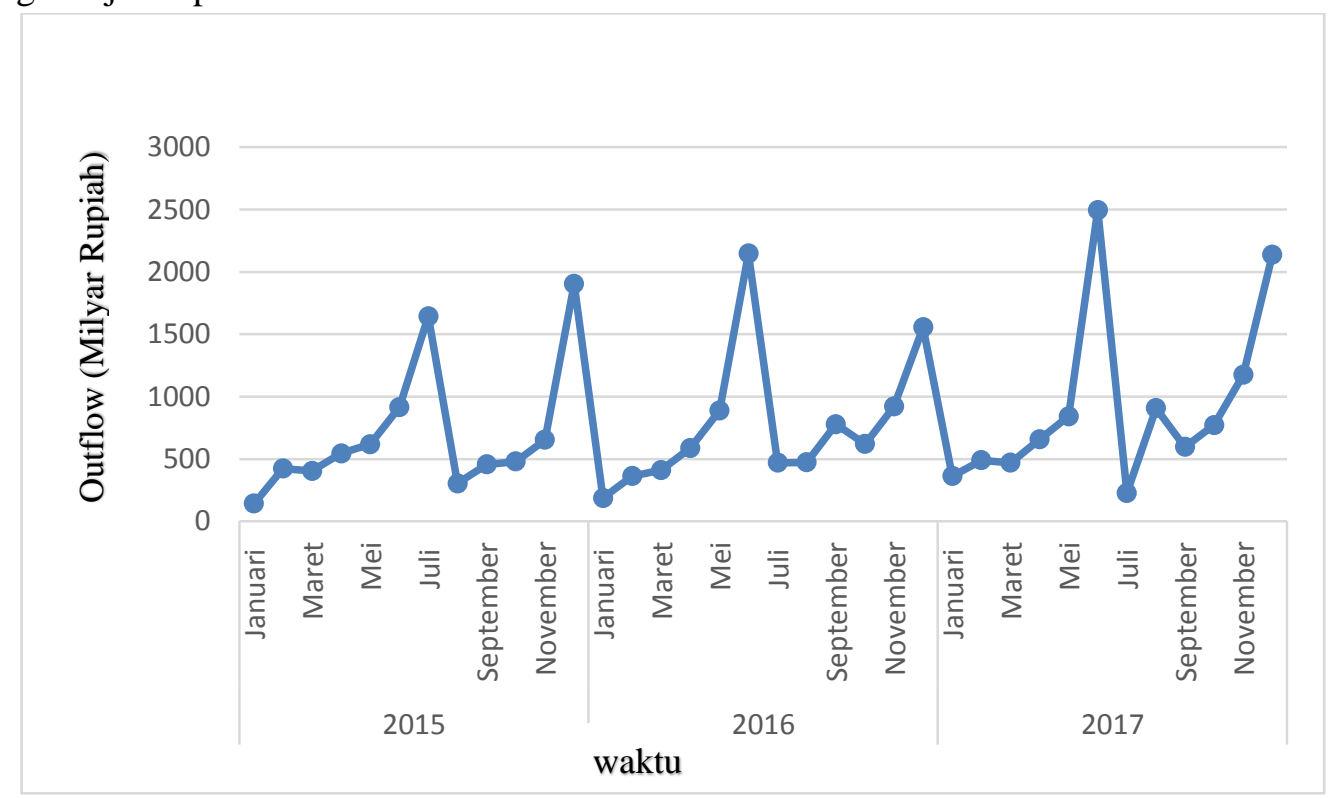

Gambar 1 Grafik outflow uang kartal di Kalimantan Barat

Gambar 1 menunjukkan bahwa terdapat fluktuasi pada data outflow di Kalimantan Barat, sehingga data mengandung pola musiman. Data outflow tersebut juga menunjukkan bahwa perubahannya masih terbilang stabil.

Langkah awal yang harus dilakukan sebelum memasuki langkah-langkah dalam tahap dekomposisi adalah menentukan window length. Nilai window length berada pada rentang $2<L \leq 18$. Window length dihitung dengan membandingkan hasil forecasting in sample dengan data out sample. Penentuan window length (L) ini dilakukan dengan tanpa grouping menggunakan aplikasi RStudio. Hasil penghitungan trial and error terhadap data outflow uang kartal di Kalimantan Barat diperoleh nilai $L$ yang optimum pada $L=8$.

Setelah menentukan window length langkah selanjutnya adalah dekomposisi. Langkah dekomposisi diawali dengan embedding yang menghasilkan matriks lintasan $L \times K$. Data yang digunakan dalam langkah ini adalah data in sample, untuk nilai $L=8$, maka $K=36-8+1=29$. Sehingga diperoleh matriks lintasannya adalah berukuran $8 \times 29$, berdasarkan Persamaan (1) menghasilkan matriks berikut.

$$
\mathbf{T}_{x}=\mathbf{T}_{i, j(8,29)}=\left[\begin{array}{cccc}
141,3884 & 422,2595 & \ldots & 842,7860 \\
422,2595 & 403,6973 & \ldots & 2.495,5060 \\
403,6973 & 544,7802 & \ldots & 227,2875 \\
544,7802 & 617,6888 & \ldots & 907,3601 \\
617,6888 & 915,3113 & \ldots & 596,9492 \\
915,3113 & 1.644,334 & \ldots & 772,1399 \\
1.644,334 & 303,5567 & \ldots & 1.173,7804 \\
303,5567 & 456,4291 & \ldots & 2.138,6446
\end{array}\right]
$$

Sebelum mencari nilai Singular Value Decomposition (SVD) tahap yang harus dilakukan adalah membentuk matriks baru $\mathbf{S}$ sesuai Persamaan (2) menggunakan matriks $\mathbf{T}_{x}$ yang sudah diperoleh. Berdasarkan Persamaan (2) diperoleh matriks $\mathbf{S}$ sebagai berikut. 


$$
\mathbf{S}_{i, j(\mathbf{8 , 8})}=\left[\begin{array}{llll}
21675306 & 16534598 & \cdots & 16866209 \\
16534598 & 27882865 & \cdots & 26844493 \\
14752432 & 17042093 & \cdots & 20031195 \\
14936797 & 16959677 & \cdots & 17700559 \\
14704019 & 16349462 & \cdots & 17340529 \\
17439682 & 16543565 & \cdots & 18154257 \\
21739983 & 20239444 & \cdots & 18870170 \\
16866209 & 26844493 & \cdots & 31100708
\end{array}\right]
$$

Tahap selanjutnya dalam dekomposisi ini adalah SVD yang menghasilkan eigentriple yaitu eigenvalue, eigenvector, dan matriks $W$-correlation yang ditampilkan bersama bentuk grafiknya. Nilai eigentriple ini digunakan untuk memisahkan komponen, sehingga komponen ini dapat dikelompokan. Grafik-grafik berikut akan menjadi dasar dalam grouping pada tahapan rekonstruksi data.

Tahapan SVD ini dimulai dengan menentukan singular value $\left(\sqrt{ } \lambda_{i}\right)$. Singular value merupakan akar dari eigenvalue. Matriks yang digunakan untuk memperoleh eigenvalue adalah matriks trajectory S. Hasil dari singular value dapat dilihat pada Tabel 2.

Tabel 2 Eigenvalues dan singular values

\begin{tabular}{ccc}
\hline No. & Eigenvalues & Singular Values \\
\hline 1 & 151992676,6200 & 12328,5310 \\
2 & 17812518,9600 & 4220,4880 \\
3 & 15560350,4000 & 3944,6610 \\
4 & 11076435,9800 & 3328,1280 \\
5 & 10971530,0300 & 3312,3300 \\
6 & 10654916,7700 & 3264,1870 \\
7 & 3271052,0500 & 1808,6050 \\
8 & 1889816,5900 & 1374,7060 \\
\hline
\end{tabular}

Langkah selanjutnya adalah untuk mendapatkan eigenvector. Nilai dari eigenvector ini digunakan untuk mempermudah dalam menentukan karakteristik data dari matriks trajectory. Hasil eigenvector dari matriks trajectory $\mathbf{S}$ adalah sebagai berikut.

$$
\mathbf{U}=\left[\begin{array}{cccccccc}
-0,3219 & 0,1392 & -0,4546 & 0,0027 & 0,0777 & -0,1757 & -0,7448 & -0,2803 \\
-0,3722 & -0,5260 & -0,0666 & -0,0013 & 0,0005 & 0,2649 & 0,2869 & -0,6540 \\
-0,3397 & -0,0351 & 0,4391 & -0,1211 & 0,0036 & -0,8088 & 0,1027 & -0,1054 \\
-0,3403 & 0,2802 & 0,3600 & 0,3489 & 0,6927 & 0,2702 & -0,0222 & 0,0312 \\
-0,3388 & 0,3777 & 0,2879 & -0,6589 & -0,2840 & 0,3732 & -0,0714 & -0,0194 \\
-0,3476 & 0,3662 & -0,0745 & 0,5987 & -0,5842 & 0,0219 & 0,1983 & 0,0051 \\
-0,3701 & 0,1071 & -0,6013 & -0,2542 & 0,2623 & -0,1213 & 0,4723 & 0,3446 \\
-0,3922 & -0,5796 & 0,1282 & 0,0797 & -0,1529 & 0,1317 & -0,2903 & 0,6019
\end{array}\right]
$$

Tahap berikutnya adalah principal component. Tahap ini menggunakan nilai singular value dan eigenvectors yang telah diperoleh dari matriks trajectory $\mathbf{S}$. Berdasarkan perhitungan pada Persamaan (3) hasil princival component yang didapat adalah sebagai berikut.

$$
\mathbf{V}_{(29,8)}=\left[\begin{array}{cccccccc}
-1780,4032 & 390,3164 & -559,1046 & -46,2202 & 64,7859 & -1,6488 & 871,1580 & 970,2269 \\
-634,9260 & 306,9159 & 219,2037 & 1817,4567 & -736,9928 & 193,1900 & 87,4818 & -121,6776 \\
\vdots & \vdots & \vdots & & \vdots & & \vdots & \vdots \\
-894,7695 & -1554,7455 & -201,7799 & 228,9542 & 210,0494 & 953,1459 & 259,8755 & -179,7615
\end{array}\right]
$$

Lebih jelasnya pola dari SVD dapat dilihat pada Gambar 2. 


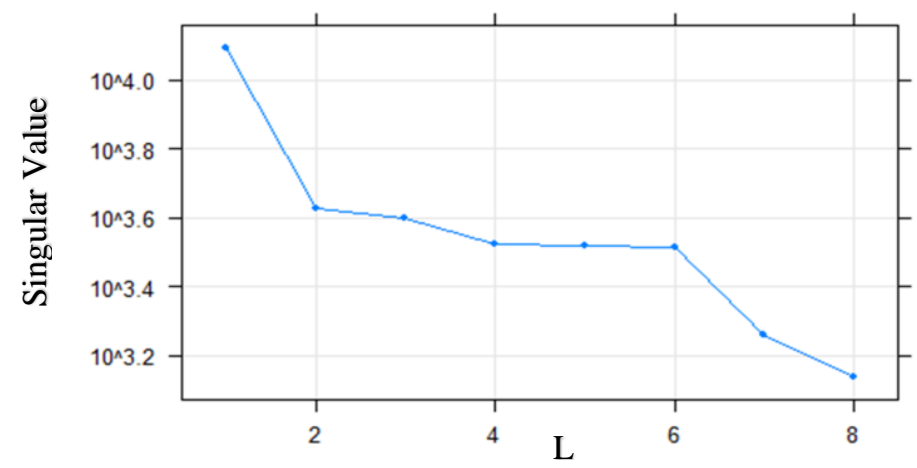

(a)

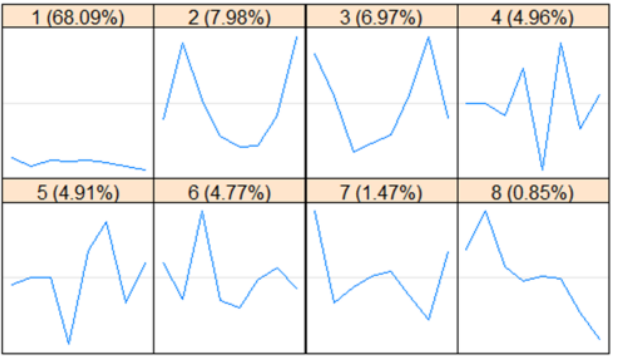

(b)

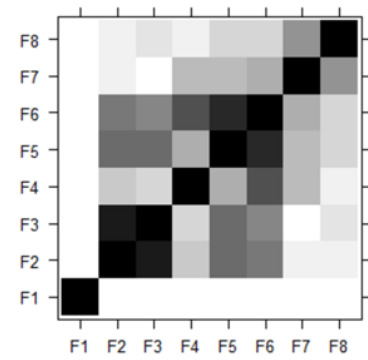

(c)

Gambar 2 (a) grafik singular value (b) grafik eigenvector (c) matriks W-Correlations

Berdasarkan Gambar 2 (a) grafik eigenvalue menunjukkan banyaknya grouping yang terbentuk yaitu 3 kelompok berdasarkan patahan yang terbentuk. Gambar 2 (b) menunjukkan bahwa eigenvector 1 mempengaruhi data sebesar $68,09 \%$, eigenvector 2 mempengaruhi data sebesar $7,98 \%$, eigenvector 3 mempengaruhi data sebesar $6,97 \%$, eigenvector 4 mempengaruhi data sebesar $4,96 \%$, eigenvector 5 mempengaruhi data sebesar $4,91 \%$, eigenvector 6 mempengaruhi data sebesar $4,77 \%$, eigenvector 7 mempengaruhi data sebesar $1,47 \%$, dan eigenvector 8 dengan pengaruh paling kecil terhadap data yaitu sebesar $0,85 \%$. Grafik eigenvector juga menunjukkan masing-masing anggota dari masingmasing kelompok yang dilihat dari kemiripan pola. Gambar 2 (c) menunjukkan korelasi antar data yang lemah.

Tahapan rekonstruksi data merupakan tahapan yang sangat penting dalam SSA. Pada tahap ini, berdasarkan pada Gambar 2 jumlah kelompok yang ditetapkan dalam tahap grouping adalah sebanyak 3 kelompok. Kelompok 1 diberi nama trend, kelompok 2 diberi nama season 1, dan kelompok 3 diberi nama season 2 sesuai dengan pola dari masing-masing kelompok tersebut. Berdasarkan kemiripan pola pada grafik eigenvector dan besarnya pengaruh eigenvector tersebut terhadap data. Kelompok trend terdiri dari eigentriple 1, season 1 terdiri dari eigentriple 2,3 dan season 2 terdiri dari eigentriple 4,5,6,7. Eigentriple 8 tidak dimasukkan ke dalam kelompok karena pengaruh eigenvector 8 terhadap data paling kecil yaitu sebesar $0,85 \%$.

Setelah mendapatkan kelompok dan anggota dari masing-masing kelompok, tahapan selanjutnya adalah diagonal averaging. Diagonal averaging diperoleh dengan menjumlahkan hasil rekonstruksi untuk tiap kelompok dengan menggunakan Persamaan (4). Hasil rekonstruksi outflow uang kartal dapat dilihat pada Tabel 3. 
Tabel 3 Hasil rekonstruksi outflow uang kartal

\begin{tabular}{cccccc}
\hline & & \multicolumn{3}{c}{ Hasil Rekontruksi } & Diagonal \\
\cline { 3 - 5 } No. & Data & Trend & Season 1 & Season 2 & Average \\
\hline 1 & 141,3884 & 573,2276 & 324,4223 & $-643,9164$ & 253,7335 \\
2 & 422,2595 & 629,9356 & $-123,3105$ & 39,6147 & 546,2398 \\
3 & 403,6973 & 632,8666 & $-289,3260$ & 54,7714 & 398,3120 \\
4 & 544,7802 & 642,0664 & $-128,09427$ & 8,2683 & 522,2405 \\
$\vdots$ & $\vdots$ & $\vdots$ & $\vdots$ & $\vdots$ & $\vdots$ \\
35 & $1.173,7804$ & 1148,0651 & 215,1209 & $-148,5560$ & 1214,6299 \\
36 & $2.138,6446$ & 1306,4183 & 844,6935 & 95,7465 & 2246,8584 \\
\hline
\end{tabular}

Kedekatan dan kemiripan bentuk dari hasil rekonstruksi dapat dilihat pada Gambar 3.

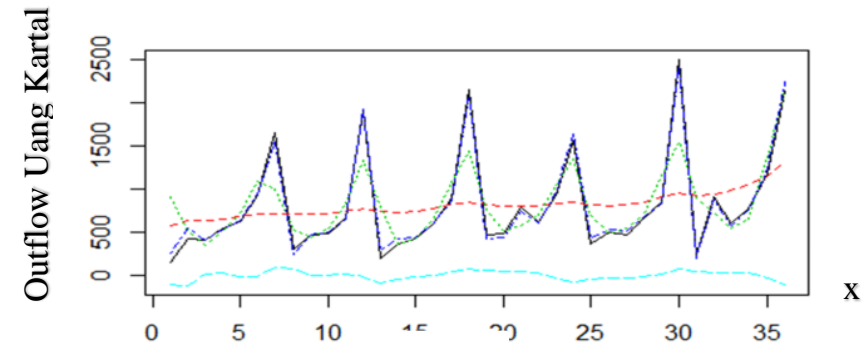

(a)

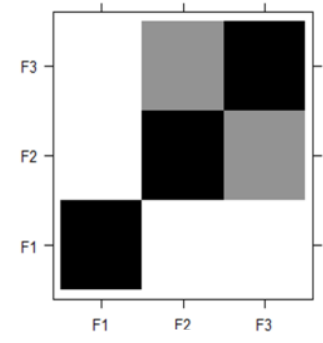

(b)

\section{Gambar 3 (a) hasil rekonstruksi tahap grouping, (b) matriks W-Correlation setelah rekonstruksi}

Dari Gambar 3 (a) hasil rekonstruksi data hampir mendekati data aslinya. Gambar 3 (b) dapat dilihat adanya strong separability saat masing-masing kelompok tidak lagi berkorelasi. Hal ini mengakibatkan bahwa rekonstruksi menggunakan SSA dengan window length $(L)=8$ dan grouping $=$ 3 kelompok dapat dikatakan baik.

Langkah selanjutnya adalah peramalan menggunakan metode $R$-forecasting. Algoritma pada peramalan $R$-forecasting berkaitan dengan penaksiran koefisien Linear Recurrent Formula (LRF) atau $a_{j}$ yang dihitung berdasarkan eigenvector pada tahap SVD dengan menggunakan aplikasi RStudio. Data yang digunakan pada tahap $R$-forecasting adalah data hasil rekonstruksi pada tahap diagonal averaging. Berdasarkan Persamaan (5) koefisien dari LRF dapat dilihat pada Tabel 4.

Tabel 4 Koefisien Linear Recurrent Formula $\left(a_{j}\right)$

\begin{tabular}{cc}
\hline No. & $\boldsymbol{a}_{\boldsymbol{j}}$ \\
\hline 1 & 0,4952538 \\
2 & 0,3918369 \\
3 & $-0,1272117$ \\
4 & 0,1403106 \\
5 & 0,0442653 \\
6 & 0,02787991 \\
7 & 0,03612966
\end{tabular}

Tabel 4 memperlihatkan bahwa terdapat 7 koefisien dari LRF, dimana ada 1 koefisien yang bernilai negatif. Hasil koefisien LRF ini akan digunakan dalam perhitungan peramalan. 
Langkah selanjutnya adalah menentukan model persamaan SSA untuk meramalkan outflow uang kartal di Kalimantan Barat. Model ini dibentuk berdasarkan koefisien LRF yang telah diperoleh. Berdasarkan Persamaan (6), adapun model persamaan untuk meramalkan outflow uang kartal adalah sebagai berikut:

$$
g_{i}=0,4952538 g_{i-1}+0,3918369 g_{i-2}+\left(-0,1272117 g_{i-3}\right)+\cdots+0,0361297 g_{i-7} .
$$

Model peramalan yang diperoleh kemudian divalidasi menggunakan sejumlah indikator. Akurasi peramalan pada penelitian ini menggunakan indikator Mean Absolute Percentage Error (MAPE) dan Tracking Signal.

Perhitungan akurasi peramalan dilakukan dengan membandingkan hasil ramalan in sample dengan data out sample. Perbandingan ini dilakukan untuk melihat apakah model tersebut layak atau tidak untuk meramalkan outflow uang kartal di Kalimantan Barat. Berdasarkan perhitungan menggunakan persamaan SSA yang telah diperoleh maka didapat hasil perbandingan data out sample dan hasil peramalan untuk outflow uang kartal di Provinsi Kalimantan Barat yang disajikan pada Tabel 5.

Tabel 5 Perbandingan data out sample dan hasil peramalan

\begin{tabular}{ccc}
\hline Periode & $\begin{array}{c}\text { Data } \\
\text { Out Sample } \\
\text { (Milyar Rupiah) }\end{array}$ & $\begin{array}{c}\text { Hasil Ramalan } \\
\text { (Milyar Rupiah) }\end{array}$ \\
\hline Januari 2018 & 133,5 & 157,1695 \\
Februari 2018 & 758,6 & 864,2044 \\
Maret 2018 & 685,9 & 711,8246 \\
April 2018 & 617,4 & 709,2159 \\
Mei 2018 & 1543 & 1732,9850 \\
Juni 2018 & 2409,7 & 2070,9910 \\
Juli 2018 & 446,2 & 184,8302 \\
Agustus 2018 & 999,3 & 920,2649 \\
September 2018 & 600,1 & 812,4110 \\
Oktober 2018 & 863,6 & 796,1540 \\
\hline
\end{tabular}

Tabel 4.5 menunjukkan bahwa data ramalan yang diperoleh hampir mendekati data aktual (out sample). Kedekatan tersebut diperoleh dari MAPE dan tracking signal yaitu sebesar 18,63\% dan 0,6377. Berdasarkan nilai MAPE dan tracking signal tersebut metode SSA dapat dikatakan layak untuk meramalkan outflow uang kartal di Kalimantan Barat.

\section{PENUTUP}

Berdasarkan hasil analisis dan pembahasan yang telah dilakukan, maka dapat diperoleh beberapa kesimpulan, yaitu sebagai berikut:

1. Model persamaan SSA yang terbaik untuk meramalkan outflow uang di Kalimantan barat adalah $g_{i}=0,4952538 g_{i-1}+0,3918369 g_{i-2}+\left(-0,1272117 g_{i-3}\right)+\cdots+0,0361297 g_{i-7}$.

2. Akurasi hasil ramalan dihitung menggunakan MAPE dan tracking signal. MAPE dan tracking signal dari ramalan untuk metode SSA adalah 18,63\% dan 0,6377 dengan window length (L) sebesar 8. Berdasarkan nilai MAPE dan tracking signal tersebut, maka dapat dikatakan metode SSA cocok digunakan pada peramalan selanjutnya karena MAPE dan tracking signal masih berada di batas toleransi.

\section{DAFTAR PUSTAKA}

[1] Bank Indonesia. 2013. Bank Indonesia. www.bi.go.id. [9 November 2018].

[2] Bank Indonesia. 2016. Data Penelitian Kurs dan Inflasi. www.bi.go.id. [9 November 2018]. 
[3] Solikin dan Suseno. Pengertian, Penciptaan dan Peranan Uang dalam Perekonomian. Jakarta: Pusat Pendidikan dan Studi Kebanksentralan (PSSK), 2002.

[4] Gerai Info. Pengedaran Uang: yang Penting Pas Agar Ekonomi Nggak Kolaps. Edisi XVI Tahun 2. Jakarta: Bank Indonesia, 2011.

[5] Golyandana, Netrutkin, dan Zhigljavsky. Analysis of Time Series Structure SSA and Related Techniques. Chapman dan Hall, 2001.

[6] Golyandina dan Zhigljavsky. Basic Singular Spectrum Analysis and Forecasting with R. Computational Statistics and Data Analysis. 2013; 71: 34-954.

[7] Jatmiko, Y.A., Rahayu, R.L., dan Darmawan, G. Perbandingan Keakuratan Hasil Peramalan Produksi Bawang Merah Metode Holt-Winters dengan Singular Spectrum Analysis (SSA). Jurnal Matematika. 2017; 3(1): 13-23.

[8] Bovas, A., dan Ledolter, J. Statistical Methods for Forecasting. New York: John Wiley and Son Inc, 1983.

\section{AGENG WICAKSONO}

HELMI

YUNDARI
: Universitas Tanjungpura, Jl. Prof. Dr. H. Hadari Nawawi, agengwicaksono9711@gmail.com

: Universitas Tanjungpura, Jl. Prof. Dr. H. Hadari Nawaawi, helmi132205@yahoo.co.id

: Universitas Tanjungpura, Jl. Prof. Dr. H. Hadari Nawawi, yundari@math.untan.ac.id 